\title{
College Students with Disabilities and Study Abroad: Implications for International Education Staff ${ }^{1}$
}

\author{
Brenda G. H a m e is t e r \\ The Pennsylvania State University \\ Pet e r R. M a t the w s \\ University of Colorado at Colorado Springs
}

\section{Nathaniel S. Hosley}

Lock Haven University of Pennsylvania

\section{Margo Coffin Groff}

The Pennsylvania State University

A student who is legally blind approaches a staff member in International Education and asks for large-print or audiocassette information about studying in Spain. Another student with a GPA that is too low to qualify him for study abroad asks that an exception be made because the effects of his disability lowered his grades. A third student tells her academic advisor that study abroad cannot be part of ber college plan because she has a learning disability and needs taped books and readers for her exams.

\section{Introduction}

International Education staff are facing issues like these as they seek to expand participation in study abroad programs to college students with disabilities. Although published statistics about participation rates are lacking, students with disabilities have traditionally been underrepresented in study abroad programs (Sygall, 1994; Bucks, 1997). Participation in 
study abroad programs, however, is increasing (Burn, Cerych, and Smith, 1990; National University Continuing Education Association, 1994) as part of a larger trend in which American colleges and universities are acting to internationalize their curriculum, to enroll more international students, and to encourage more of their American students to participate in study abroad experiences. The increasing number of students studying overseas is expected to include more older students, more students from diverse racial and ethnic backgrounds, and more students with disabilities (Desruisseaux, 1992).

Students with disabilities are underrepresented in study abroad. This article outlines five concepts that are important when seeking to include students with disabilities in study abroad-individualization, barriers and accommodations, disability spread, inclusion, and collaboration. The article addresses frequently asked questions about disability issues and presents two vignettes of students with disabilities interested in study abroad. It is emphasized that students with disabilities are, first and foremost, students. As significant as a student's disability may appear to be, it often has relatively little significance to study abroad. If international educators are to be successful in serving students with disabilities, they must work closely with others, especially disability services staff.

\section{Who Are Students with Disabilities?}

According to the Americans with Disabilities Act of 1990, a "person with a disability" is someone with a physical or mental impairment that substantially limits one or more major life activities. Major life activities include caring for oneself, performing manual tasks, walking, seeing, hearing, speaking, breathing, learning, and working. An individual is considered to be a person with a disability if he or she currently has the disability, has a record of having the disability, or is regarded as having the disability (Jarrow, 1992).

Disabilities may be both visible and invisible. University staff may readily identify students with physical disabilities or neurological impairments who use wheelchairs or crutches, and students with sight loss who use guide dogs or white canes. Invisible disabilities are obviously not as apparent. One example of an invisible disability is a learning disability. Students with learning disabilities make up the largest subgroup of stu- 
dents with disabilities in postsecondary education ("This Year's Freshmen," 1997). Other invisible disabilities include hearing loss; chronic health impairment (such as diabetes, asthma, cardiac problems); speech impairment; psychological, mental, and emotional impairments; and attention deficit disorder. A HEATH Resource Center report concluded that 9.2 percent (or 142,010 students) of all first-time, full-time college freshmen in 1994 had a disability (Henderson, 1995). Severity of disabilities varies from those of a mild nature, needing limited support, to those that are more severe, requiring very extensive or pervasive support.

College students with disabilities have all the same concerns as do nondisabled students, such as choosing a career, making friends, or getting good grades. Some unique, disability-related concerns may also be present, such as locating adaptive equipment, finding accessible facilities and parking, or having the physical stamina to traverse a college campus (Hameister, 1989).

Due to the magnitude of students with learning disabilities on our campuses, this population takes on special significance and, at times, has been surrounded by controversy. Learning disabilities were recently brought to national attention in the 1997 decision Guckenberger v. Boston University.

(T) he court found that it was not so much what Boston University did, but how it did it and its motivations, that violated the law. The court took issue with... (the president's) personal opinions, stereotypes and fears based on popular press and his failure to seek to either educate bimself or consult with appropriate experts regarding learning disabilities or fasbioning reasonable accommodations. (Simon, 1997, p.1)

To address some of these concerns, the Association on Higher Education and Disability (AHEAD, 1997) published "Guidelines for Documentation of a Learning Disability in Adolescents and Adults." It discussed qualifications of the evaluator, documentation, substantiation of the learning disability, recommendations for accommodations, and confidentiality. Included in the substantiation section was information on the diagnostic interview, assessment, specific diagnosis, test scores, and clinical summary. 


\section{Research B a ckground}

Since 1985, a regional network of public and private institutions of higher education in Pennsylvania has been promoting the international exchange of students with disabilities. This network, called "No Barriers to Study," shares information about resources and strategies for successful study abroad experiences. In 1989, a literature review and telephone survey of experts in disability services were used to create a survey of student perceptions of study abroad (Hameister, Matthews, \& Skolnick, 1991; Matthews, Hameister, \& Skolnick, 1992).

A survey of 64 students with disabilities conducted by "No Barriers to Study" members found that a majority of the students ( 83 percent) had considered and were interested in studying abroad, primarily to experience the cultural benefits. Most students wanted to learn more about study abroad, specifically the available services, financial resources, and countries that they could visit. Students overwhelmingly favored an inclusionary study abroad program, as opposed to a program just for students with disabilities (Matthews, Hameister, \& Hosley, 1998).

Students with disabilities who participated in study abroad cited increased confidence, a broader awareness of their abilities, as well as stronger communication and problem-solving skills. These attributes were appealing to prospective employers (Snow, 1991). Nondisabled students reported experiencing similar benefits (Opper, Teichler, \& Carlson, 1990; Swinger, 1985).

Our previous publications have discussed study abroad from the perspective of disability services providers; this article will focus on implications for international education staff. Our purpose is to share some concepts that we have found helpful in working with students with disabilities and hopefully to stimulate discussion on this topic. We are not focusing in this article on the legal requirements for nondiscrimination (see Rubin, 1996 for a summary of the issues) or on disability culture. We feel that collaboration between international educators and disability services staff will help to resolve many of the emerging questions about determining responsibility for accommodations and access to programs. We believe that by including students with disabilities, all students are better served. 


\section{Relevant Concepts for Including Students with Disabilities in Study Abroad Program s}

It is impossible to list all of the accommodations that should be made for individual students with disabilities traveling to different study abroad locations and majoring in different fields. The best approach for international educators is to have a solid background in concepts relevant to including students with disabilities in study abroad, and to work together with the student, the disability services provider, and the study abroad site in the planning process.

Our list of relevant concepts is based on three sources of information: our collective experience at diverse postsecondary institutions and input from colleagues as we worked with students with disabilities who were seeking study abroad experiences; the results of our structured interviews with students with disabilities about their perceptions of study abroad; and a review of the literature relating to study abroad and disability issues. From these experiential and research areas, five interrelated concepts emerged as especially important when seeking to include students with disabilities in study abroad.

\section{Individualization}

Every individual has a unique background and a unique combination of interests, skills, and capacities (Van der Klift \& Kunc, 1994). Students acquire disabilities at different ages, learn to use different types of compensatory strategies and adaptive equipment, and develop varying levels of independence and assertiveness. For example, two students who are hard of hearing may have different proficiency in speechreading (lipreading) and unequal willingness to initiate speech with strangers. These individual characteristics will influence the study abroad experience.

Students with disabilities may also be adult students or minority students - other groups that may be underrepresented in study abroad programs (Ganz, Osborn, \& Primak, 1993; Opper, Teichler, \& Carlson, 1990). When all of these characteristics are combined with the variables of academic major and choice of study abroad program, it is apparent that 
each student's study abroad planning will be different. Each student will be the best resource as to his/her needs for accommodation. Since the true experts on accessibility are persons with disabilities, it is important to involve potential participants with disabilities in problem solving and program planning (Sygall, 1995).

\section{Barriers and Accommodations}

The related concepts of barriers and accommodations are basic to serving students with disabilities. In this context, barriers refer to any obstacles that could impede the study abroad experience. Barriers may be psychological as well as physical. Examples of possible obstacles to study abroad include transportation barriers, financial barriers, architectural barriers, the lowered expectations of others, or dependence on family for independent living.

Accommodations refer to the supports, services, or policy changes that enable students with disabilities to participate fully in activities. Sample accommodations for study abroad include accessible transportation, sign language interpreters, financial assistance, or the support and encouragement of family and friends.

Sixty-four undergraduate students with disabilities were asked to rank the importance of a list of possible barriers to study abroad and the importance of a list of possible accommodations. Important factors for some students were length of the program, access to assistive devices and services, financial support options, the time required for planning, and the availability of academic accommodations such as note-takers, readers, modified testing arrangements, and interpreters. A majority of students in our study preferred study abroad programs of one semester and wanted at least six months advance notice before studying abroad (Matthews, et al., 1998).

Individual students ranked barriers and accommodations differently, according to factors such as type of disability, compensatory strategies used, use of adaptive equipment, and previous travel experience (Matthews, et al., 1998). Therefore, as suggested by the previous section on "individualization," identification of potential barriers and potential accommodations for study abroad is made on an individual basis.

Providing accommodations for persons with disabilities is appropri- 
ate when designing publicity materials and events to publicize study abroad programs. For example, written materials should be offered in modified formats (large print, computer disk, cassette tape) to students with visual impairments. Events should be held in physically accessible facilities with amplification systems or sign language interpreters, if needed. The welcome extended by staff, quality of interaction, and the accessibility of introductory information will influence students' persistence in learning more about study abroad.

\section{Disability Spread}

Another concept relevant to including students with disabilities is based on the phenomenon of disability spread as identified by Dembo, Leviton and Wright (Wright, 1983). Disability spread refers to the tendency for nondisabled persons to exaggerate the impact of a disability based on stereotypes and myths about the type of disability.

Every individual is a unique combination of interests, abilities, experiences, and idiosyncracies. When someone's disability is seen as the largest component of their personality, we only see the person's limitations, not their unique and human characteristics (Van der Klift \& Kunc, 1994).

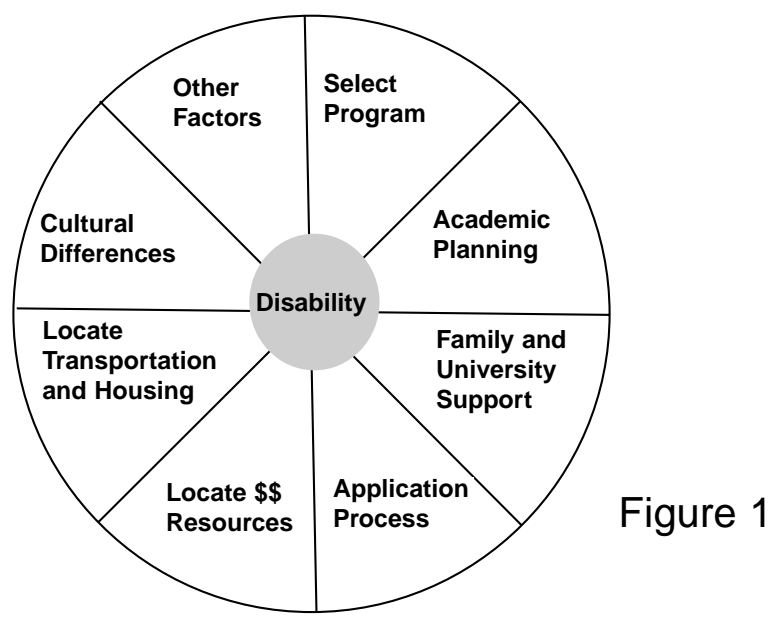

Figure 1 shows how we can apply this concept to the study abroad experience. In this example, a student has a variety of experiences related to study abroad—selecting a program, academic planning, ensuring fam- 
ily and university support, navigating the application process, locating financial resources, arranging transportation and housing, learning about cultural differences, and other factors. The student also has a disability. Although the disability has some impact on each of the sectors, it is a relatively minor part of the study abroad experience.

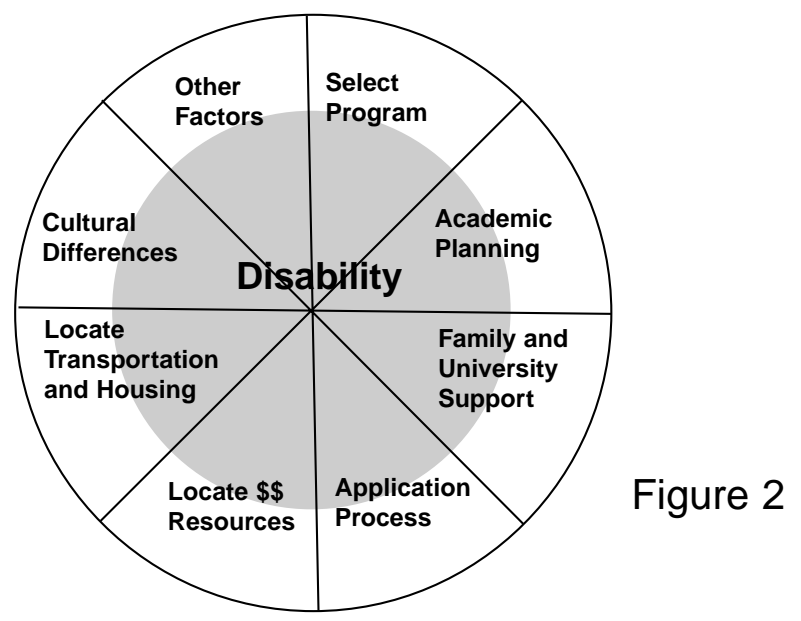

If we allow disability spread to occur, as shown in Figure 2, the disability becomes prominent. The other typical experiences of study abroad take on less importance as we are distracted by the impact of the disability.

The attitudes of university staff (in international education, disability services, or academic advising), and indeed the attitude of the student, will influence whether the presence of a disability is seen as just one more unique characteristic of a student or as the main, overwhelming characteristic. Our focus should be on each student's specific abilities and interests, not on disability myths and stereotypes.

\section{Inclusion}

An important tenet of both Section 504 of the 1973 Rehabilitation Act and the 1990 Americans with Disabilities Act is the need to include persons with disabilities in activities with nondisabled persons, rather than providing separate activities (US Equal Employment Opportunity Commission \& US Department of Justice, 1992; National Council on Disability, 1996). It is an incorrect perception that students with disabil- 
ities are "happiest with their own kind." As noted earlier, students in our research strongly favored participating in an inclusionary study abroad program (Matthews, et al., 1998).

Since students with disabilities will be involved in inclusionary programs, preparation takes on added significance. This can be facilitated by the insights of returning students who can help prepare students with disabilities for the attitudes and levels of access that they will encounter while studying abroad. Feeling prepared for handling the attitudes and customs will ease adjustment. Students may be surprised to discover that their "Americanness" is a greater factor in their acceptance abroad than their disability (Ganz, Osborn \& Primak, 1993).

\section{Collaboration}

International educators are familiar with the collaboration needed to develop and implement study abroad programs. Academic advisers, onsite coordinators, students, parents, and financial aid staff are all important contributors to the process. Including students with significant disabilities in study abroad creates an opportunity for similar collaboration with disability services providers on campus. Disability services staff can provide information about the types of accommodation (e.g., adaptive computers, audiotaped textbooks) that students with disabilities can use to meet the new challenges of a study abroad program. Colleagues in disability services may also be helpful in identifying resources for acquiring adaptive devices or services. Providing timely, accurate and complete information about study abroad options and available accommodations will encourage more students with disabilities to consider seriously this opportunity for personal and professional enhancement (Matthews, et al., 1998).

Formal collaboration between international education and disability services has been tried and advocated by the University of Minnesota (Soneson \& Aune, 1997) and by the "No Barriers to Study" consortium in Pennsylvania (Matthews, et al., 1998). On a national level, an important collaborative effort began in 1996 between Mobility International USA (MIUSA), the United States Information Agency (USIA) and 16 international exchange and disability-related organizations. This joint effort, the "National Clearinghouse on Disability and Exchange," promotes equal 
opportunities for persons with disabilities to participate in international educational exchange, community service, and travel. The Clearinghouse provides information and referrals for individuals interested in international exchange programs, as well as publications and an electronic database of resources (Houston, 1996).

\section{Frequently Asked Questions from International Educators}

With these five concepts in mind, we will respond to several questions that we hear frequently from international education staff.

\section{Resources. How can international educators find the resources to} provide appropriate services to students with disabilities?

International educators can gain more support for their efforts and be more effective at helping students with disabilities to study abroad if they collaborate actively with their colleagues, the disabilities services staff. Getting study abroad and disabilities staff together begins the educative process and the cross-fertilization of information that will enable the two groups of professionals to help this particular group of students find suitable — and accommodating — study abroad sites.

Advising students with disabilities is a time-consuming process, but if the study abroad staff member is informed about what questions to ask the student about his or her needs and then asks those questions of the overseas site colleagues, the process of finding a good match for the student will move along.

Mobility International USA has several outstanding publications that promote international opportunities for people with disabilities. This organization offers information about air travel for people with disabilities, scholarships for study abroad, and disability access and attitudes in particular localities (see their web site at http://www.miusa.org).

Additional support and information is being developed by Access Abroad, a three-year Fund for the Improvement of Post-Secondary Education (FIPSE) grant. A collaborative effort between study abroad and disability services professionals at the University of Minnesota, the Pennsylvania State University, and the Institute for the International Education of Students (IES), Access Abroad is conducting needs assess- 
ments and developing a multimedia website and a model for advising and accommodating students with disabilities. The project's overall intent is to enhance study abroad opportunities for students with disabilities.

Through these resources, study abroad and disabilities service staff can get a better idea of what services are available and what a particular culture's attitudes are toward different kinds of disabilities. Understanding the cross-cultural aspects of disability attitudes around the world is a huge undertaking and can be highly subjective and fraught with peril if we make assumptions based on our understanding of United States' attitudes or law.

Study abroad and disability services professionals need to discuss these attitudes and differences more frequently at both domestic and international conferences and in smaller groups as well. There are no pat answers and tidy descriptions - nor is there an easy answer about how many of our institution's standards can be imposed on a host institution when it comes to accommodating students with disabilities that we send them.

2. Appropriate Destinations. Which destinations, programs, or countries are the most hospitable to students with disabilities?

No study abroad professionals know all the appropriate destinations, but they can draw on their own experiences and that of their colleagues in the Section on US Study Abroad listserve (SECUSS-L). As an anecdotal example, two recent students, one with a learning disability and another who uses a wheelchair, have been accommodated at a university in England. With extensive pre-planning, a student who is blind worked with study abroad staff to locate a good match for his academic interests and for his adaptive equipment needs at a university in Australia. Although we have yet to send a student with a vision disability to Phillip Universität in Marburg, Germany, that university is well-equipped to accommodate students with sight loss.

After several countries and universities are identified as a good match, more detailed issues of disability access should be examined. Two resource guides have been developed to provide information about types of accommodations and accessible programs at institutions of higher education. The guides are based on a survey of 600 institutions in Europe, Canada, and the United States (Gagliano \& Moore, 1996; Van Acker, 
1996). Of course, confirmation of this information should be sought directly from the host institution before sending a student, since services may change.

When international educators conduct regular on-site visits abroad, they can collect information about the disability services provided at each institution. This information is invaluable in helping students identify accessible study abroad programs.

3. Documentation of a disability. How do international education staff request and evaluate medical and psychological documentation?

It is not the responsibility of international educators to request documentation of disabilities from medical or other professionals. Nor is it their responsibility to interpret such documentation. Most campuses have assigned an individual or an office with this kind of responsibility for disability services. This office takes responsibility for the collection of medical, psychological and/or psychoeducational information documenting the presence of a disability. Location of this function in the organizational structure can vary widely; student affairs, student services, health services, and undergraduate education are possible sites. Services for students with learning disabilities are sometimes administered separately from services for students with other types of disabilities.

The purpose of documentation is to provide validation that a disability exists and to provide information and/or some indication regarding the functional limitations created by the disability. The information is signed by a certified professional qualified to diagnose in the area of disability. General guidelines and standards for documentation are provided in the law and by professional organizations such as the Association on Higher Education and Disability (website: http://www.ahead.org). Disability services providers use each student's documentation when responding to reasonable accommodation requests from the student and planning for accommodation requests from other university offices, in collaboration with the student.

Eligibility criteria for participation in study abroad are the same for students with and without disabilities. As in the example at the beginning of this article, students with disabilities will sometimes ask that an exception be made to a requirement because of the effects of their disabil- 
ity. Universities can hold all students to eligibility requirements for study abroad programs. However, if the university has appeals processes or a history of considering special requests for study abroad from nondisabled students, then it should consider similar requests from students with disabilities for exceptions to policies.

In our experience, students have occasionally expressed the need to contact the home institution for a copy of their disability documentation. These are students who did not expect to use disability accommodations while abroad, but who decided later that accommodations were advisable. Offices of disability services inform each student about the types of services that he or she is eligible to receive, but the final decision about using or not using the services belongs to the student.

\section{What is reasonable accommodation?}

Accommodations are intended to permit equal participation in academic and other programs of a university. There is a common misperception, particularly with learning disabilities, that accommodations are advantages given to individuals with disabilities. However, properly designed and implemented accommodations are intended to create access to education and give students an opportunity to meet the standards of an academic program. The law does not intend that accommodations should reduce academic standards.

A frequent accommodation for students with learning disabilities is extended test time. Extended time is often helpful because the student with a learning disability may have processing difficulties. The student often understands the information but is slower to process it auditorally or visually. If the standard for the course is to understand the material, then extending test time to allow a student to express the material may be entirely appropriate. If, on the other hand, speed is an essential function and an integral part of the standard, then extending time may be an inappropriate accommodation.

The term "reasonable accommodation" also implies that the request by a student for accommodation must not place undue hardship upon the university. Undue hardship has been generally defined to include the circumstance of undue financial burden or an action that would fundamentally alter the nature of a program or standard. In practice, reasonableness has also been interpreted by some to include giving an institution a rea- 
sonable amount of time to respond to a request for accommodations. Therefore, if a student suddenly chooses to announce that he or she has a disability while sitting in a classroom in a foreign country, the home institution may take the necessary time to gather appropriate documentation, evaluate the request and implement the accommodation. How much time is a subjective matter. The best recommendation is to be diligent in responding and to document your efforts.

5. Liaison with Disability Service Providers. What is the role of the disability services provider? How can international education staff establish a working relationship with disability services providers?

Disability services staff handle all disability-related issues, such as locating accessible housing, transportation, or adaptive equipment. They also ensure access to programs and services, such as student organizations, academic majors, internships, and study abroad. Most disability services offices do not try to duplicate the services provided by other campus offices. Instead, they become knowledgeable about modifications in policies, procedures, equipment, and other supports that enable students with disabilities to participate fully in campus life. Another role of the disability services office is offering professional development programs to other university offices about disability issues and the intent of nondiscrimination legislation.

Collaboration with your disability provider begins with getting to know each other, how you operate, what processes are used in each office, why you do what you do. A willingness to commit the time is often the biggest barrier. Disability offices have seen exponential growth during the past decade, and international education offices have seen very similar growth with the renewed focus on participation in international education opportunities. If opportunities are to be provided to this underrepresented population of students, a commitment of time for collaboration between these offices is a minimal requirement.

\section{Two Case Studies}

We have prepared two vignettes to illustrate the participation of students with disabilities in study abroad. The descriptions which follow represent a composite of characteristics from several actual students. 
International education staff may find these examples helpful as they work through the study abroad process with students with disabilities at their campuses.

\section{Student \# 1 -John}

John is a 20-year-old history major with a 3.1 GPA. Early in his sophomore year, he inquires about study abroad after talking with a staff person in disability services. John is legally blind, uses a white cane for mobility and large print or audiotaped text books. He can read magnified print on the computer screen. He received some mobility orientation training when he first enrolled at the campus.

John carefully explains the kinds of adaptive equipment that he uses in college. He would like to find a study abroad program offering the same accommodations in either Spain or England. John has previously traveled to Mexico with a high school group. He requests information about the study abroad programs in either large print or on audiotape.

John selects three universities that have formal exchange relationships with his institution. An adviser in International Education contacts her counterparts at these universities and requests information about services and adaptive equipment for students with low vision. After reviewing all the academic, social, and disability services information, John selects one university which will meet his needs. He notifies the host institution in advance about his anticipated needs and his excitement about the study abroad experience.

Thanks to his thorough planning and the assistance of study abroad and disability services staff, John subsequently has a very successful study abroad experience. He locates housing on campus to minimize walking and learning new routes. He is able to use the computer equipment, test accommodations, and other services at the host institution. John travels extensively, often with small groups, but also by himself. His family is pleased that he is able to arrange for lodging and sightseeing by himself. John enjoys speaking with other students about the benefits of study abroad when he returns to his home campus.

\section{Student \#2-Kristin}

Kristin is a 23-year-old business administration major. She has a 2.6 GPA and has completed 64 credits toward her degree. She has a learning 
disability which affects reading comprehension and auditory processing. She receives extended time for taking tests and priority registration through disability services. She audiotapes some of her classes to help with taking notes and uses taped books. Kristin has previously traveled to Canada with her family.

Although her grades are improving each semester, Kristin's cumulative GPA is lower than she expected. She has not considered study abroad because of the disability accommodations that she uses daily.

At an advising meeting, Kristin's academic adviser asks if she has considered study abroad. After her adviser's encouragement, Kristin talks to her friends and her parents and then seeks out study abroad information. She worries that her financial aid could not be used for study abroad and that she could not afford the international experience. She asks International Education staff if other students with learning disabilities have preceded her and what their study abroad experiences were. Fortunately, the university can identify a former participant with a learning disability who can reassure Kristin. Kristin eventually chooses to attend a study abroad program with a strong business program and excellent services for students with learning disabilities.

While studying abroad, Kristin finds that her professors are willing to let her tape lectures and class discussions and that studying with a small group of her classmates is very helpful. She keeps in contact with the disability services office and uses some of their advice about note-taking strategies. She completes the program successfully and reports a new interest in international business opportunities.

\section{Discussion}

Both John and Kristin fit the profile of students in our research sample. Their ages, disabilities, accommodation needs, and previous travel histories are not uncommon. Both John and Kristin chose to disclose their disabilities in advance so that adaptive equipment and services could be located. In our experience, students, study abroad advisers, and academic advisers (faculty) have each contacted other universities to find one that can meet the student's needs. There is no single model for assigning this responsibility.

John's request for information about study abroad opportunities in a different format (e.g., large print or audiotape) is a valid request for access 
to information. Information can be printed from a computer in a larger font, or the information can be read aloud and taped, possibly by a volunteer or work study student. It is also likely that John can access the information from the university's web pages by using adaptive computer software to enlarge the print. These are relatively low-cost accommodations.

Kristin has a common concern about her financial aid package. When students pay tuition to their home institutions but attend a study abroad program, their financial aid packages generally travel with them. In addition, specific scholarships for study abroad may be available through international education offices or off-campus agencies. Scholarships for students with disabilities exist at some schools, and these may often be used for study abroad experiences.

We cannot predict the actual accommodations and services needed by Kristin and John just by knowing their type of disability. Other students with sight loss, for example, may use a guide dog and require readers for exams. Students with learning disabilities may use tutors and assistance with study skills. Overall, the critical factor is finding a good match between the individual characteristics of the student and the facilities and services of the host institution.

How students assimilate the study abroad experience is just as important as the details of the experience itself. What students learn from the experience and how the experiential knowledge becomes a part of their life upon reentry are key. One returning student with a disability stated that he now "looks at every person differently" and that his "life experience is forever changed."

\section{Conclusion}

Students with disabilities are first and foremost students. As significant as their disability may appear to be, it often has relatively little significance to the study abroad experience. Other factors, such as selecting a program, academic planning, gaining family support, locating resources and housing, transportation plans, and cultural differences are often of far greater importance. In other words, the same issues that concern all students concern students with disabilities. Disability-specific issues can usually be translated into minimizing barriers to increase accessibility, and providing individual, collaborative, and inclusive accommodations 
and supports.

University staff may yearn for a concise set of rules for what they must do to allow students with disabilities to study abroad, but such rules do not exist. Disability services, instead, is about applying common sense, good will, creativity, and knowledge about the intent of nondiscrimination legislation to the needs and interests of individual students.

Our goal is to help international education staff collaborate with disability service providers and others in delivering services to students with disabilities. While writing this article, we experienced our own collaborative process as we discussed issues from the perspective of international education staff, disability services staff, and special education faculty. The vocabulary, concepts, and processes are slightly different in each field. We learned from each other and feel that our final product is stronger as a result. We predict that the collaboration of international education and disability services staff, students with disabilities, academic advisers, and others will result in similar benefits for including students with disabilities in study abroad programs.

\section{Not e}

1 The authors thank Kendall Brostuen (Lock Haven University) and Barbara Rowe (Bucknell University) for their time and expertise in providing input to this article. A special thanks to Susan Birdsey (Lock Haven University) for her technical assistance and preparation of the manuscript.

\section{Refere nces}

AHEAD (1997, July). Guidelines for documentation of a learning disability in adolescents and adults. Columbus, $\mathrm{OH}$ : Author.

Bucks, C. (Ed.). (1997). A world of options: A guide to international exchange, community service and travel for persons with disabilities (3rd ed.). Eugene, OR: Mobility International USA.

Burn, B., Cerych, L. \& Smith, A. (Eds.). (1990). Study abroad programmes. Higher Education Policy Series 11, Vol. 1. London: Kingsley. 
Desruisseaux, P. (1992, November 25). An older, more diverse group of American students is expected to participate in study-abroad programs. The Chronicle of Higher Education, p. A28.

Gagliano, G. V. \& Moore, N. M. (1996). Studying abroad: A guide to accessible university programs and facilities for students with disabilities. New Orleans, LA: University of New Orleans.

Ganz, M. A., Osborn, J. \& Primak, P. (1993). Promoting student diversity. In W. Hoffa, J. Pearson, \& M. Slind, (Eds.), NAFSA's guide to education abroad for advisers and administrators (pp. 111-123). Washington, DC: NAFSA: Association of International Educators.

Hameister, B. G. (1989). Disabled students. In M. L. Upcraft \& J. N. Gardner and Assoc., The freshman year experience: Helping students survive and succeed in college (pp. 340-351). San Francisco: Jossey-Bass.

Hameister, B. G., Matthews, P. R. \& Skolnick, B. D. (1991). Disabled students' perceptions of study abroad. Selected proceedings of the 1990 AHSSPPE Conference (pp. 4-6). Columbus, OH: AHSSPPE.

Henderson, C. (1995). College freshmen with disabilities. A triennial statistical profile. Washington, DC: American Council on Education.

Houston, P. (1996, June/July). National clearinghouse on disability and exchange. Information from $H E A T H, 11-12$. (Available from HEATH Resource Center, National Clearinghouse on Postsecondary Education for Individuals with Disabilities, American Council on Education, One Dupont Circle, NW, Suite 800, Washington, DC 20036-1193)

Jarrow, J. E. (1992). Title by title: The ADA's impact on postsecondary education. (Available from the Association on Higher Education and Disability, P.O. Box 21192, Columbus, OH 43221-0192)

Matthews, P. R., Hameister, B. G., \& Hosley, N. S. (1998). Attitudes of colleges students toward study abroad: Implications for disability service providers. Journal of Postsecondary Education and Disability, 13(2), 67-77.

Matthews, P. R., Hameister, B. G., \& Skolnick, B. D. (1992). No barriers to study: A study abroad questionnaire. Woolrich, PA: Clinton Consulting and Counseling.

National Council on Disability. (1996). Achieving independence: The challenge for the 21st century. Washington, DC: Author.

National University Continuing Education Association. (1994). Lifelong 
learning trends.

Opper, S., Teichler, U., \& Carlson, J. S. (1990). Impacts of study abroad programmes on students and graduates. Higher Education Policy Series 11, Vol, 2. London: Kingsley.

Rubin, A. M. (1996, September 27). Students with disabilities press colleges to help them take part in foreign study. The Chronicle of Higher Education, p. A47-48.

Simon, J. (1997, September). Guckenberger v. Boston University . . .a long awaited decision. AHEAD Alert 21, (5), 1,4.

Snow, S. M. (1991, Fall). A powerful catalyst: International travel can help you get a job. Careers and the disABLED, 46-48.

Soneson, H. M. \& Aune, B. P. (Winter, 1997). Collaborative approaches to promoting international study for students with disabilities. A World Awaits You. Eugene, OR: Mobility International USA.

Swinger, A. (1985). Planning for study abroad. Bloomington, IN: Phi Delta Kappa Foundation.

Sygall, S. (1994). Travel and exchanges: A round-up of information and contacts. Transitions Abroad, 17(5), 80-81.

Sygall, S. (1995). Facilitating exchange: Including persons with disabilities in international programs. Transitions Abroad, 18(5), 87-89.

This year's freshmen: A statistical profile. (1997, January 17). The Chronicle of Higher Education, pp. A42-A43.

US Equal Employment Opportunity Commission \& US Department of Justice. (1992). Americans with Disabilities Act Handbook (ISBN 0-16038148-7). Washington, DC: US Government Printing Office.

Van Acker, M. (1996). Studying abroad: European guide for students with disabilities. Leuven, Belgium: Catholic University of Leuven.

Van der Klift, E. \& Kunc, N. (1994). Beyond benevolence. Friendship and the politics of help. In J. S. Thousand, R. A. Villa, \& A. I. Nevin (Eds.), Creativity and collaborative learning: A practical guide to empowering students and teachers. (pp. 391-401). Baltimore: Brookes.

Wright, B. (1983). Physical disability—A psychosocial approach (2nd ed.). New York: Harper and Row. 